\title{
IN VITRO EFFECT OF DIFFERENT INACTIVATORS ON RABIES VIRUS
}

\section{KOTB, ATTYAT, M. ${ }^{1}$, AMANI A. SALEH ${ }^{1}$, MONA A.M. HELAL ${ }^{2}$, NORA E.SHAHEIN ${ }^{2}$ and M.H. KHODEIR ${ }^{1}$}

1. Veterinary Serum and Vaccine Research Institute, Abbassia, Cairo, Egypt

2. Faculty of Girls for Arts, Science and Education, Ain Shames University.

(Manuscript received $2^{\text {nd }}$ June 2014)

\begin{abstract}
$\Lambda$ scorbic acid, Beta propilacton and binary ethylenamine (BEA) were evaluated as inhibitors of rabies' virus (EvelyRetkitincki-Abeleseths skauis) in optimized BHK21 cell cutrures. Ascorbic acid inactivated rabies virus at concentrations of $0.1,0.5$ and $1 \mathrm{mg} / \mathrm{ml}$ after 22,18 and 14 hours at $37^{\circ} \mathrm{C}$ respectively, while BPL inactivated the virus after $4,6,8$ hours with concentrations of $1 / 500,1 / 10000$, and $1 / 20000$ respectively at $37^{\circ} \mathrm{C}$. BEI inactivated the virus after 6 hours when used with $0.3 \mathrm{M}$. These Inactivators did not affect the antigincity of rabies virus in three prepared experimental vaccine batches. Ascorbic acid appears to be the most preferable one as safe natural noncarcinogenic agent when compared with BPL and BEI.
\end{abstract}

\section{INRODCTION}

Rabies is a highly fatal infectious disease affecting most worm blooded animals including man. It is an infection of the central nervous system which is usually fatal (OIE 2012). El-Gaballi (2008) reported that there is an increasing in the number of bitten persons by street dogs representing a huge problem facing the ministry of health. Number of affected persons was 121509 in 2003. This number reached 207694 during 2007 with a medication cost of 25 million Egyptian pounds. Since rabies is known to be an incurable disease, so vaccination is a powerful tool in combating the disease. WHO (1996) recommended the prevention of usage of all live vaccine to be administrated for vaccination either in humans or in animals to avoid the recurrence vicinal strains. In order to elicit the production of a safe inactivated vaccine for immunization of pet and farm animals has been recommended.

Since rabies virus is highly neurotropic and can cause fatal encephalitis, necessary precautions should be taken while handling. Inactivation of rabies virus is essential for preparation of vaccines, diagnostic reagents and research purposes (Madhusudana et. al., 2004).

The present study aims to comparatively evaluate the inactivation effect of $\beta P L ; B E I$ and ascorbic acid on rabies virus to select the best inactivator that provides the safe and potent vaccine. 


\section{MATERIALS AND METHODS}

\section{1-Rabies virus strains}

\section{1-Vaccinal strain}

Evely-Retkitincki-Abeleseths (ERA) strain of rabies virus adapted on $\mathrm{BHK}_{21}$ cell culture (Wunner, 1985) was supplied by the Department of Pet Animal Vaccine Research (DPAVR); Veterinary Serum and Vaccine Research Institute (VSVRI).

\section{2-Challenge strain}

Challenge rabies virus strain (C.V.S) was adapted on mice brain. It has a titer of $10^{3.5} \mathrm{MLD}_{50} /$ mice (Minimum lethal dose). This virus was used in the test of National Institute of Health (NIH test) to detect the antigenic value of the experimentally prepared vaccine batches. This virus was supplied by DPAVR.

\section{2- Reference Vaccine}

Defensor-R vaccine supplied by Mycoform, U.K. was used as a reference vaccine in NIH test.

\section{3-Baby Hamster kidney cell culture (BHK-21)}

BHK-21 cell culture was supplied by DPAVR for propagation of rabies virus and virus titration. These cells were passaged and maintained using minimum essential medium (MEM) supplemented with $10 \%$ new born calf serum.

\section{4-Virus titration}

Virus titration was carried out using the micro-titer technique according to WHO (1996) and the virus titer was calculated according to Reed and Muench (1938).

\section{5- The influence of cell culture density on the titer of the rabies virus}

\section{(Multiblicity of infection "MOI")}

To determine the optimal concentration of $\mathrm{BHK}_{21}$ cells, which could be infectedwith ERA strain, different cell densities have been investigated for virus productivity after being infected with the virus. Cells were counted by using modified Fachs Rosental.

\section{6- Effect of sequential cell growth on rabies virus productivity}

Different times of cell culturing have been followed to investigate the optimal time of virus infection that yield the highest virus titer. The cell line has been infected at zero time, 18 hours, 24 hours and 48 hours post culturing.

*Cell virus infection was carried out using a multiplicity of infection (MOI) of 1.04: 1. 


\section{7-Chemicals}

\section{1- Ascorbic acid and copper sulphate}

These salts were supplied by Sigma Chemical Company (USA).Stock solutions containing $0.01 \mathrm{M}$ of copper sulphate and $0.5 \mathrm{M}$ of ascorbic acid were prepared and sterilized by membrane filtration. The stock solutions were added to the virus suspension to obtain a final concentration of $5 \mu \mathrm{g} / \mathrm{ml}$ of copper sulphate with 3 concentrations of ascorbic acid $(0.1 \mathrm{mg} / \mathrm{ml}, 0.5 \mathrm{mg} / \mathrm{ml}$ and $1 \mathrm{mg} / \mathrm{ml})$.

\section{2- Beta propiolactone (BPL)}

B. propiolactone reinst (2. oxetanone research grade) $\mathrm{C}_{3} \mathrm{O}_{2}$ of M.W. 72.06 was supplied by SERVA electrophoresis/D. 69115 Heidel barge Carl. Benz str.7. It was prepared according to kopowski (1996) where 3 different molarities $(1 / 5000 ; 1 / 10000 \& 1 / 20000)$ were prepared in double distilled water.

\section{3- Binary Ethylenamine (BEI)}

Bromo ethylamine hydro bromide $95 \%$ f.w. $204.90 \mathrm{HV}$ was supplied by Aldrich chemical Co. Ltd Grillingham Dorest. England. It was prepared according to Girard et. al., (1977) where different molarities (0.01; 0.02 and 0.03$)$ were prepared in $0.5 \mathrm{M}$ of sodium hydroxide.

\section{4- Sodium thiosulphate solution}

It was used at a final concentration of $2 \%$ to stop the reaction of the inactivators (BPL and BEI).

\section{5- Aluminum hydroxide gel $\left(\mathrm{AlOH}_{3}\right)$}

Aluminum hydroxide gel $2 \%$ was supplied by Superfos Biosector, Denmark. It was used as adjuvant to the prepared inactivated rabies vaccine experimental batches.

\section{6- Trypan blue stain}

$5 \%$ trypan blue stain was used to determine cell viability and counts during preparation $\mathrm{BHK}_{21}$ cell culture.

\section{8- Preparation of experimental inactivated rabies vaccine batches}

Different portions of rabies virus infected fluid (obtained from infected BHK-21 cell culture) were subjected to inactivation processes using the above mentioned chemicals at $37^{\circ} \mathrm{C}$ with determination of the less time allowing complete virus inactivation. Complete virus inactivation was confirmed by virus titration in cell culture and mice inoculation that revealed zero virus titer and safety for mice. $20 \%$ of $\mathrm{AlOH}_{3}$ was added to the inactivated virus as adjuvant and subjected to quality control tests as recommended by WHO (1996). 


\section{9- Mice}

Albino Swiss mice, 3-4 weeks old, were bred in the mice colony in the Department of Pet Animal Vaccine Research. Theses mice were used for titration of CVS virus, test of National Institute of Health (NIH) and safety of the prepared vaccines.

\section{0-Test of the National Institute of Health (NIH)}

NIH was carried out to evaluate the antigenic value of the prepared vaccine batches according to WHO (1996) where this value should be not less than 0.3.

\section{RESULTS AND DISCUSSION}

Table 1. Effect of initial seeding density of $\mathrm{BHK}_{21}$ cells on the infectivity titre of rabies virus

\begin{tabular}{|c|c|c|}
\hline $\mathrm{BHK}_{21}$ cell concentration $\left(\mathrm{X} 10^{4} / \mathrm{ml}\right)$ & $\begin{array}{l}\text { Virus infectivity titer }\left(\log _{10} \mathrm{TCID}_{50}\right. \\
\qquad / \mathrm{ml})\end{array}$ & $\begin{array}{l}\text { Multiplicity of infection } \\
\text { (MOI) }\end{array}$ \\
\hline 1.5 & 7.8 & $5.2: 1$ \\
\hline 1.75 & 5.2 & $2.98: 1$ \\
\hline 3.0 & 6.2 & $2.06: 1$ \\
\hline 3.75 & 6.7 & $1.78: 1$ \\
\hline 7.5 & 7.8 & $1.04: 1$ \\
\hline 8.75 & 4.1 & $0.48: 1$ \\
\hline
\end{tabular}

Table 2. Effect of sequential cell growth on ERA rabies virus productivity

\begin{tabular}{|c|c|}
\hline $\begin{array}{c}\text { Age of cell culture } \\
(\text { HPS } *)\end{array}$ & $\begin{array}{c}\text { Virus infectivity titer } \\
\left(\log _{10} \text { TCID }_{50} / \mathrm{ml}\right)\end{array}$ \\
Zero & 7.8 \\
$18 \mathrm{HPS}=60-70 \%$ confluence & 7.8 \\
$24 \mathrm{HPS}=80-90 \%$ confluence & 7.8 \\
$48 \mathrm{HPS}=100 \%$ confluence & 6.5 \\
\hline
\end{tabular}

$* \mathrm{HPS}=$ hours post seeding (Time of incubation) 
Table 3. Inactivation of ERA rabies virus by BPL at $37^{\circ} \mathrm{C}$

\begin{tabular}{|c|c|c|c|c|c|c|c|c|c|c|c|c|c|}
\hline & \multicolumn{10}{|c|}{ Virus infectivity titer $\left(\log _{10}\right.$ TCID $\left._{50} / \mathrm{ml}^{2}\right)$ on HPI* } \\
\cline { 2 - 14 } Conc. & 0 & 2 & 4 & 6 & 8 & 10 & 12 & 14 & 16 & 18 & 20 & 22 & 24 \\
Of BpL & HPI & HPI & HPI & HPI & HIP & HPI & HPI & HPI & HPI & HPI & HPI & HPI & HPI \\
\hline $1 / 5000$ & 7.8 & 2.4 & 0 & 0 & 0 & 0 & 0 & 0 & 0 & 0 & 0 & 0 & 0 \\
$1 / 10000$ & 7.8 & 4.5 & 2.3 & 0 & 0 & 0 & 0 & 0 & 0 & 0 & 0 & 0 & 0 \\
$1 / 20000$ & 7.8 & 5.7 & 3.5 & 1.2 & 0 & 0 & 0 & 0 & 0 & 0 & 0 & 0 & 0 \\
\hline
\end{tabular}

$* \mathrm{HPI}=$ hours post inactivation

Table 4. Inactivation of ERA rabies virus by $\mathrm{BEI}$ at $37^{\circ} \mathrm{C}$

\begin{tabular}{|c|c|c|c|c|c|c|c|c|c|c|c|c|c|}
\hline \multirow{2}{*}{$\begin{array}{c}\text { Conc. } \\
\text { Of BEI }\end{array}$} & \multicolumn{10}{|c|}{ Virus infectivity titer $\left(\log _{10}\right.$ TCID $\left._{50} / \mathrm{ml}\right)$ on HPI* } \\
\cline { 2 - 13 } & 0 & 2 & 4 & 6 & 8 & 10 & 12 & 14 & 16 & 18 & 20 & 22 & 24 \\
& HPI & HPI & HPI & HPI & HPI & HPI & HPI & HPI & HPI & HPI & HPI & HPI & HPI \\
\hline $0.01 \mathrm{M}$ & 7.8 & 6.8 & 5.4 & 4.3 & 3.2 & 2.6 & 2.1 & 1.6 & 1.2 & 0 & 0 & 0 & 0 \\
$0.02 \mathrm{M}$ & 7.8 & 6.3 & 4.8 & 3.1 & 1.7 & 1.3 & 0 & 0 & 0 & 0 & 0 & 0 & 0 \\
$0.03 \mathrm{M}$ & 7.8 & 4.6 & 2.4 & 0 & 0 & 0 & 0 & 0 & 0 & 0 & 0 & 0 & 0 \\
\hline
\end{tabular}

$* \mathrm{HPI}=$ hours post inactivation

Table 5. Inactivation of ERA rabies virus by ascorbic acid at $37^{\circ} \mathrm{C}$

\begin{tabular}{|c|c|c|c|c|c|c|c|c|c|c|c|c|c|}
\hline \multirow{2}{*}{$\begin{array}{c}\text { Conc. } \\
\text { Of ascorbic }\end{array}$} & \multicolumn{10}{|c|}{ Virus infectivity titer (log 10 TCID $_{50} / m \mathrm{~m}$ ) on HPI* } \\
\cline { 2 - 13 } acid & 0 & 2 & 4 & 6 & 8 & 10 & 12 & 14 & 16 & 18 & 20 & 22 & 24 \\
$(\mathrm{mg} / \mathrm{ml})$ & HPI & HPI & HPI & HPI & HPI & HPI & HPI & HPI & HPI & HPI & HPI & HPI & HPI \\
\hline 0.1 & 7.8 & 7.3 & 6.8 & 6.1 & 5.5 & 4.2 & 3.3 & 2.5 & 2.0 & 1.6 & 1.1 & 0 & 0 \\
0.5 & 7.8 & 7.1 & 6.5 & 5.8 & 4.6 & 3.7 & 2.8 & 2.1 & 1.5 & 0 & 0 & 0 & 0 \\
1.0 & 7.8 & 6.5 & 5.9 & 5.1 & 3.5 & 2.3 & 1.1 & 0 & 0 & 0 & 0 & 0 & 0 \\
\hline
\end{tabular}

$* \mathrm{HPI}=$ hours post inactivation

Table 6. Final evaluation of the prepared inactivated vaccine

\begin{tabular}{|c|c|c|}
\hline Type of vaccine & Safety in mice & Antigenic value by NIH \\
\hline BpL inactivated vaccine & Safe & 2.3 \\
BEI inactivated vaccine & Safe & 2.2 \\
Ascobic acid inactivated vaccine & Safe & 2.2 \\
Defensor reference vaccine & Safe & 2.5 \\
\hline
\end{tabular}


Concerning the preparation of an inactivated rabies virus for vaccine production, the present work optimized some conditions for yielding a high virus titer to be suitable for preparation of a potent inactivated vaccine.

Table (1) showed the influence of cell density on the replication of ERA rabies virus in $\mathrm{BHK}_{21}$ cells with different concentration (cell seeding densities) reflecting that the virus titer was significantly decreased in culture with the highest cells density(8.75 $\left.x 10^{4}\right)$. Low cell density $\left(1.75 \times 10^{4}\right)$ was not as successful as anticipated, the thing which could be attributed to the high alkalinity required for virus replication affecting cellular division where the used medium for virus replication should be maintained at pH (7.4-7.6) (Wiktor, 1973).

The best cell concentration was found to be from $1.5 \times 10^{4}$ to $7.5 \times 10^{4}$ cells/ml. This result is similar to that obtained by Chapman et. al.(1973) and with Wiktor (1973) who found that the range of cell counting of $0.5 \times 10^{6}$ to $2.5 \times 10^{6}$ cells/ $\mathrm{ml}$ resulted in increased infective antigen titre and immunogenicity but not in direct proportion.

The yielding of infective rabies virus in $\mathrm{BHK}_{21}$ cells supported these finding as shown in table (2) where the highest titer was obtained when the virus infection of the cells was being carried out at $0 ; 18$ and 24 hours post seeding of the cells where the cells did not reach a complete confluence. The lower infectivity titre was obtained when the virus infection of the cells was done at 48 hours post seeding with complete confluence of cell sheet. These results came to be confirmed by Wiktor and Clark (1973) and OIE (2012) who mentioned that the total virus yield are often higher when cells are infected in suspension and then plated and allowed to grow to confluence, than in case of infection of already confluent cell sheet.

The importance of inactivated infectious viruses in preparation of inactivated vaccines or in diagnostic reagents cannot be minimized, since various degree of laboratory safety guidelines are practiced around the world (White et. al., 1986).

Through the present study two types of alkynating agents were used (BPL and $\mathrm{BEI}$ ) in comparison to Ascorbic acid. Most human commercial inactivated vaccines are inactivated by BPL (OIE, 2012). BPL acts as nucleic acid denaturant, as a result of alkulation of imidazol functional groups in the viral nucleic acid as described by Fishbei et. al., (1970).

As shown in table (3); 3 concentrations of BPL were used providing complete virus inactivation achieved after 4, 6 and 8 hours with BPL final concentrations of 1 : $5000,1: 10000$ and 1:20000 respectively. The complete virus inactivation was confirmed by cell culture infection (showing no CPE) and inoculation of weaned mice through intracerebral route (showing no rabies signs). In this respect; Nicolas et. 
al.(1978) used BPL for preparation of inactivated rabies vaccine for human use at 1 : 4000 for 24 hours at $4^{\circ} \mathrm{C}$ and 2 hours at $37^{\circ} \mathrm{C}$, while Sazonova et. al.(1980) inactivated Moscow strain in cell culture at a dilution of $1 / 8000$ for 3 hours at $4^{\circ} \mathrm{C}$ and 2 hours at $20^{\circ} \mathrm{C}$. Attyat (1988) used 1:1000 BPL to inactivate mice brain adapted rabies virus for 6 hours at $4^{\circ} \mathrm{C}$. These results confirmed that BPL inactivation rate differs according to the temperature of inactivation and type of the used tissue for virus propagation.

BEI was used for inactivation of rabies virus after cyclization of 2bromoethylamine hydrobromide in alkaline solution (sodium hydroxide) with different concentrations as shown in table (4) including $0.01 \mathrm{M} ; 0.02 \mathrm{M} ; 0.03 \mathrm{M}$. Complete inactivated rabies ERA virus was obtained after 18,12 and 6 hours post treatment with such molarities respectively. These results were confirmed by cell culture infection (showing no CPE) and inoculation of weaned mice through intracerebral route (showing no rabies signs).

Depending on the obtained results, it could be deduced that inactivation rate of rabies virus differs according to the nature of infected tissue where Larghi and Nebel (1980) used BEI with a final concentration of $1 \%$ after 3 hours.

BEI and BPL have been used satisfactorily but their use in mass production lods put the producer at a risk because they are carcinogenic materials as concluded by Nitert et. al.(1974) and White et. al.(1986).

So, there is a need to find an alternative inactivating agent which is not expensive and always available as ascorbic acid (vitamin $\mathrm{C}$ ) which is undergoing autooxidation results in the formation of $\mathrm{OH}$ groups that could induce the virus inactivation (Murata et. al., 1986). Table (5) showed that 3 different concentrations of ascorbic acid $(0.1 ; 0.5 ;$ and $1 \mathrm{mg} / \mathrm{ml})$ resulted in complete virus inactivation after 22,18 and 14 hours respectively at $37^{\circ} \mathrm{C}$. Similar findings were reported by White et. al.(1986) who used ascorbic acid to inactivate para influenza type 2 within 24 hours at $37^{\circ} \mathrm{C}$ with $1 \mathrm{mg}$ ascorbic acid/ml. The loss of infectivity did not alter either the haemagglutination or complement fixation qualities of the antigen.

Madhusudana et. al., (2004) inactivated rabies virus (CVS) strain on VERO cell culture with ascorbic acid at a concentration of $0.5 \mathrm{mg} / \mathrm{ml}$ after 72 hours at $4^{\circ} \mathrm{C}$ and 1 $\mathrm{mg} / \mathrm{ml}$ after 48 hours.

The adsorbance of rabies virus by Alhydra gel was done at a final concentration

$20 \%$ resulted in agreement with Larghi and Nebel (1980). The test of National Institute of Health (NIH) was carried out for testing the potency of the three prepared inactivated rabies vaccine experimental batches. As shown in table (6), the 3 
preparations induced high potency with antigenic value ranged from 2.2 to 2.3 and that of the reference vaccine was 2.5. These values appear to be higher than the minimum requirement antigenic value (0.3) recommended by WHO (1996).

It could be noticed that there is no difference between the effects of the different methods used for inactivation of rabies virus on the potency of the prepared vaccines except the safe use of ascorbic acid in inactivation process. These results are similar to those obtained by Madhusuana et. al., (2004).

From the present obtained results it could be concluded that ascorbic acid has a potential for being used as safe inactivating agent without affecting the antigenicity of the rabies virus.

\section{REFERENCES}

1. Kotb, Attyat, M. 1988. Studies on preparation of mice encephalon inactivated rabies vaccine M.V.Sc thesis microbiology Fac. Vet. Med Cairo Univ.

2. Chapman W.G., Ranshowl L and joamrick. 1973. Inactivated rabies vaccine produced from the Flurry LEP strain of virus grown in BHK $_{21}$ suspension cells. Am. Soc. Microbio, 26 (6): 258-862.

3. El-Gaballi. 2008. Dog bite cost 25 million Egyptian pound per year. Journal of radio and $\mathrm{TV}, 3794: 5$

4. Fishbei L. ; Flamm, W.G and Flok, H.L. 1970. Chemical mutagens Academic press In, New York.

5. Girard, H.C, Bayramoglu, O.I., ErLN and Burghut. 1977. Inactivation of viruses by binary ethylenimine. Bull. Int Ipid 87 (3-4):201-207.

6. Koprowski, H. 1996. The mouse inoculation test in laboratory technique in rabies $4^{\text {th }}$ Ed. World Health Organization 1996, 80-87.

7. Larghi, O.P and Nebel A.E. 1980. Rabies virus inactivation by binary ethylenimine . New method for inactivated vaccine production J. Clin Microbiol, $2: 120-122$.

8. Madhusudana SN, Shasmsundar R and Seeharaman. 2004. In vitro inactivation of the rabies virus by ascorbic acid. Int. J. Inf. Dis 8, 21-25.

9. Murata A, Kawaaki M, Motomatsu $H$. and Katof. 1986. Virus inactivating effect of Diso-ascorbic acid J. Nutr. Sc. Vitamine ; 32 (6) L: 559-67.

10. Nicolas, J., Falquet, R.B.; Montognon, B.D. and Soulebot, J.P. 1978. WHO/JABS Symposium on the standardization of rabies vaccines for human use produced in tissue culture Develop. Biol. Standard., 40: 17-24.

11. Nietert, W.; Kellicut, L. and Kubinski, H. 1974. DNA complexes produced by a carcinogenic B-propiolactone Cancer Res. 1974, 34: 859-861. 
12. OIE. 2012. Manual of diagnostic tests and vaccines for terrestrial animal 6th edition World Organization of Animal Health France Vol. 1 chapter 2.2.5 (2012).

13. Reed LT and Muench $H$. 1938. A simple method of calculating fifty percent end point Am: J. Hyg. $27: 493-498$.

14. Sazonova e, kunestov, S.V., PP and Ivanon V.S. 1980. Immunogennos virusa beshemstva Obrabotannogo Fenlom Beta pro Piolaktonom, iteplom vsesoyuzuyi institute biologicheskoi Promysh. lennot Moscow USSR 3: 32-33.

15. White LA, freeman Cy, Forester BD chapel WA. 1986. In vivo effect of ascorbic acid on infectivity of herpes viruses and paramyxoviruses. J. Clin. Microbiol ; 4 (4) : 527-531.

16. WHO. 1996. WHO monograph "Laboratory techniques in rabies" 3rd Ed Geneva, world Health organization series, 23:101-123.

17. Wiktor T.J. 1973. Tissue culture methods in Kaplan, M.M. Koprowski, 16 Laboratory techniques in rabies 3rd ed. Geneva WHO Monograph series , 23 :101-123.

18. Wiktor T.J. and Clark, H.I. 1973. Growth of rabies virus in cell culture in Bear, G.M. Ed. The natural history of rabies Vol. 1 New York Academic press 155-179.

19. Wunner H. 1985. Growth purification and titration of Rhabdo viruses in Mahy Bud, editor, virology : a practical approach. Oxford: IRL press $p$ 79-83. 


\section{تأثير بعض المثبطات علي فيروس السعار معمليا}

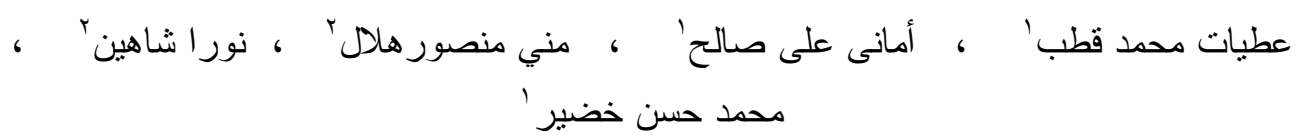

$$
\text { ا . معهز بحوث الامصال و اللقاحات البيطرية العباسبة - القاهرة. }
$$

r. ـ كلية البنات للآداب و العلوم والتربية - قسم علم الحيو ان - جامعة عين شمس - القاهرة.

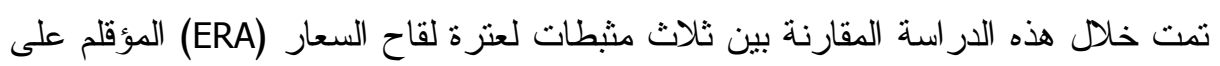

المز ارع النسيجية لكلى اليربوع السورى الذهبى (BHK21) بعد ضبط ظروف التزريع من حيث كثافة تلنة

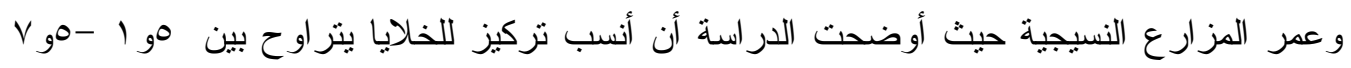

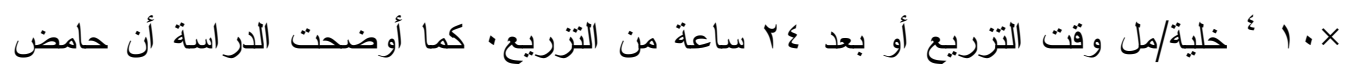

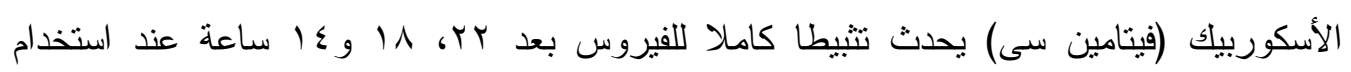

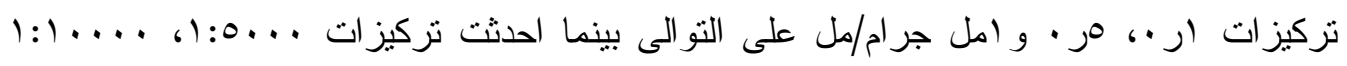

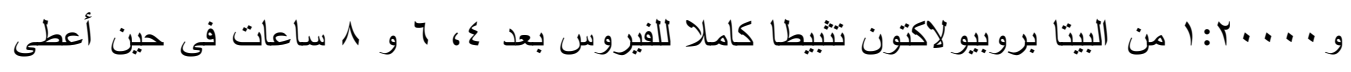

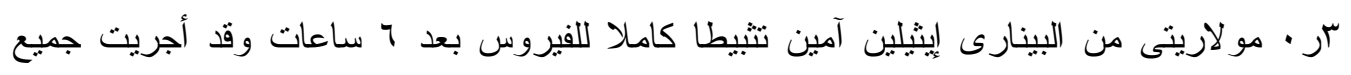

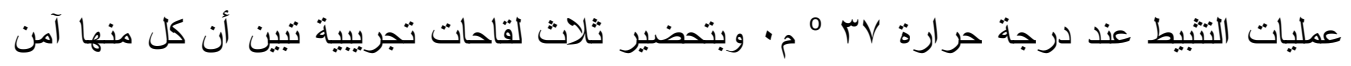

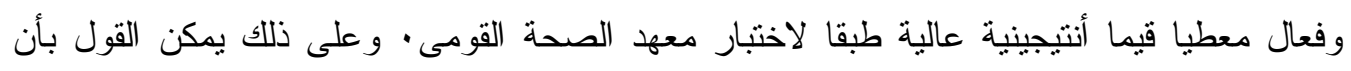

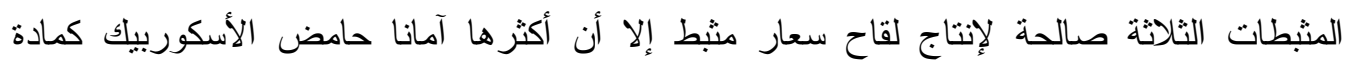

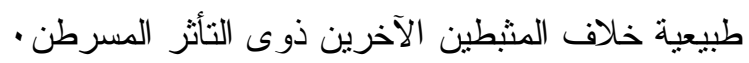

